NBER WORKING PAPER SERIES

\title{
VANISHING THIRD WORLD EMIGRANTS?
}

\author{
Timothy J. Hatton \\ Jeffrey G. Williamson \\ Working Paper 14785 \\ http://www.nber.org/papers/w14785
NATIONAL BUREAU OF ECONOMIC RESEARCH
1050 Massachusetts Avenue
Cambridge, MA 02138
March 2009

The views expressed herein are those of the author(s) and do not necessarily reflect the views of the National Bureau of Economic Research.

NBER working papers are circulated for discussion and comment purposes. They have not been peerreviewed or been subject to the review by the NBER Board of Directors that accompanies official NBER publications.

(C) 2009 by Timothy J. Hatton and Jeffrey G. Williamson. All rights reserved. Short sections of text, not to exceed two paragraphs, may be quoted without explicit permission provided that full credit, including (c) notice, is given to the source. 
Vanishing Third World Emigrants?

Timothy J. Hatton and Jeffrey G. Williamson

NBER Working Paper No. 14785

March 2009

JEL No. F22,J1,O15

\begin{abstract}
$\underline{\text { ABSTRACT }}$
This paper documents a stylized fact not well appreciated in the literature. The Third World has been undergoing an emigration life cycle since the 1960s, and, except for Africa, emigration rates have been level or even declining since a peak in the late 1980s and the early 1990s. The current economic crisis will serve only to accelerate those trends. The paper estimates the economic and demographic fundamentals driving these Third World emigration life cycles to the United States since 1970 - the income gap between the US and the sending country, the education gap between the US and the sending country, the poverty trap, the size of the cohort at risk, and migrant stock dynamics. It then projects the life cycle up to 2024. The projections imply that pressure on Third World emigration over the next two decades will not increase. It also suggests that future US immigrants will be more African and less Hispanic than in the past.
\end{abstract}

Timothy J. Hatton

RSSS -Economics

Australian National University

Canberra ACT 0200, Australia

tim.hatton@anu.edu.au

Jeffrey G. Williamson

The University of Wisconsin

350 South Hamilton Street \#1002

Madison, WI 53703

and Harvard University and CEPR

and also NBER

jwilliam@fas.harvard.edu 


\section{Country-Specific Emigration Life-Cycles}

The academic literature and media reporting is written as if the rate of Third World mass migration will increase indefinitely, at least after the current recession. It is also written from the perspective of the host country demand side, ignoring the sending country supply side, as if that supply is perfectly elastic and will remain so indefinitely. Thus, Lant Pritchett tells us that "there are five irresistible forces in the global economy creating growing pressures for greater movement of labor ... from poorer to richer countries” (2006: 138). Such statements like Pritchett’s imply that immigration rates into high-wage host countries - unless checked by tougher immigration policy or by another great depression - will rise to ever-increasing heights as the economic gap between them and the sending countries remains large, as the industrialized world ages, as its share of working native-born adults shrinks, and as the demand for additional foreign-born young adults soars to fill the gap. History strongly suggests the contrary, and it also suggests that analysts should pay much more attention to the supply side.

\section{Immigration vs Emigration: Denominators Matter}

To begin with, we need to shed our conventional Euro-centric and Americancentric instincts and look at the problem from the point view of the Third World. That is, in calculating migration rates let us begin by replacing the receiving country population or labor force in the denominator with the sending country population or labor force. After all, the growth rate of the former has been slowing down since the post-war baby boom, and in some countries, like Italy and Japan, native-born population growth is fast 
approaching zero or even negative rates. Under these demographic conditions, even constant emigration rates would yield rising immigration rates. In the denominator, when host country populations - growing so slow at the end of their demographic transition are replaced by sending country populations - growing so fast in the middle of their demographic transition, Third World emigration rates are capable of tracing out quite different patterns than those of high-wage host country immigration rates. Indeed, as we shall see below, they trace out what we have called elsewhere country-specific emigration life cycles (1998: Chp. 3; 2005: Chps. 1 and 4), and they often offer leading indicators for what to expect regarding immigration rates.

\section{European Pre-1914 Emigration Life Cycles}

Country-specific emigration life cycles across the long $19^{\text {th }}$ century make it clear that real wage or income per capita gaps will not by themselves explain emigration: during the course of modern economic growth in Europe, country emigration rates rose steeply at first from very low levels, after which the rise began to slow down as the emigration rates climbed to a peak, and subsequently they fell. This life cycle stylized fact has emerged from study after study, both for aggregate time series of country emigration rates and for regional emigration rates within countries (Gould 1979; Hatton and Williamson 2005: Chp. 4).

Several explanations have been offered for this pre-1914 stylized fact, but we have previously found Figure 1 a useful way to think about it. Here, movements along some downward-sloping home country emigration function (EM) are isolated from shifts in that function (Hatton and Williamson 1994; 1998: Chapter 2; 2005: Chp. 4). In poor, 
pre-industrial, agrarian economies, we observe low emigration rates $\left(\mathrm{e}_{0}\right)$ and low real wages or living standards $\left(\mathrm{w}_{0}\right) .{ }^{1}$ Industrialization, accumulation, and productivity advance then serve to shift the emigration function outward to EM' and to raise real wages to $\mathrm{w}_{1}$. The impact of economic growth on the home wage may be obvious, but the outward shift in the EM function may not. Indeed, the outward shift in EM dominates in this example since emigration rates have risen to $\mathrm{e}_{1}$; in the absence of the shift in EM, emigration rates would have fallen to $\mathrm{e}_{1}$. In later stages of development, EM is taken to be stable so that further improvements in real wages at home, to $\mathrm{w}_{2}$, cut back emigration rates to $\mathrm{e}_{2}$. Should EM shift backwards, the downside of the emigration life cycle will be even steeper. Thus, Figure 1 can easily reproduce the emigration life-cycle.

But what might account for the rightward shift in EM during the start of modern economic growth and its stability, or even backward shift, thereafter? The first explanation appeals to the costs of migration. Although there is certainly a strong incentive to flee pre-industrial poverty and rural subsistence, the costs are likely to be prohibitive for most poor laborers. After all, the potential migrant cannot get loans for the move (a classic case of capital market failure), and his current income is too close to subsistence to make it possible to accumulate the necessary savings to invest in some future, long distance move. Thus, enormous wage gaps between an industrial, resourcerich, high-wage country and an agrarian, resource-poor, low-wage country can be quite consistent with low emigration rates. In short, poor agrarian countries are locked in a poverty trap so that those who have the most to gain from the move are least able to exploit the opportunity. But as modern development takes hold in the home country, real

\footnotetext{
${ }^{1}$ Ceteris paribus applies to Figure 1, so conditions abroad are taken as given, including real wages. Thus, any rise in the home wage in the figure implies some catching up with high wage immigration countries.
} 
wages rise and the supply constraint on emigration is gradually released: more and more potential emigrants can now finance the move, and, in contrast with conventional theory, the home wage and emigration are positively correlated. The supply constraint is also released by greater remittances coming from an increasing stock of emigrants abroad. As industrialization at home continues, the backlog of potential migrants is slowly exhausted as more and more workers find it possible to finance the move. When the migration cost constraint is no longer binding, further increases in the real wage cause the emigration rate to decline from the peak, as conventional theory predicts.

Thus, emigration histories should pass through two regimes, the first emigrant supply constrained, and the second emigrant demand constrained, as in Figure 2. The emigrant-supply-constrained regime is consistent with rising emigration and rising home wages, and it can also be made consistent with the downward-sloping EM function in Figure 1 by appealing to rightward shifts in that function induced by absolute wage increases (as opposed to relative wages and catching up). At some point, home wages get high enough so that financial constraints are no longer binding: further increases in the home wage then reduce the emigration rate as the economy moves up and back along a more stable EM function, and emigration experience enters the demand-constrained regime. While this tale of regime switch certainly sounds plausible, we should remember that it takes no account of changing conditions in the receiving countries. If the emigration rate is ever to decline from its peak after the regime switch, the sending region has to begin catching up with the receiving region, as described in Figure 1. If it does not undergo catching up, the downside of the life cycle may never be reached. 
Of course, there are more forces driving the emigration life cycle than simply costs of the move and wage catch up. Here are three. First, even after controlling for poverty-induced cost constraints, illiteracy can be a barrier to emigration. Thus, as late $19^{\text {th }}$ century eastern and southern European countries underwent a revolution in elementary schooling (Kirk 1946; Easterlin 1981; Williamson 2007), young adults were empowered to exit, an effect sufficiently strong that they were able to leap over the literacy requirement passed by the United States Congress in 1917 to keep them out (Hatton and Williamson 2005: Chps. 8 and 9; Williamson 2007). This schooling effect should shift the EM curve in Figure 1 outward until all potential migrants are literate, ${ }^{2}$ after which EM remains stable. Second, the number at risk will matter. When countries start modern development, they also start a demographic transition: child mortality rates fall, and about two decades later the young adult cohort swells. Thus, for the same costs and benefits to a move, more will do so as the share of the population mobile rises. This too will shift the EM curve in Figure 1 outward, but as the demographic transition continues, the young adult cohort share will eventually start to shrink, and the EM curve will shift back inwards to the left. Hence, the emigration life cycle is strengthened by the demographic transition. Third, a rising stock of previous emigrants living abroad generates the well-known friends and relatives affect: by helping finance the move and lowering the cost of job search, previous emigrants serve to augment the current flow of new emigrants. This effect is big at the start of the emigrant life cycle, as the emigrant stock abroad rises steeply from low levels. But as the rate of growth in the immigrant

\footnotetext{
${ }^{2}$ Of course, what matters here is the schooling of the young prior to their reaching migration ages, not the schooling (or its absence) of the older adults they leave behind.
} 
stock in the host country slows down, so too does the friends and relatives effect, ${ }^{3}$ thus causing the EM curve to stabilize. In short, outward shifts in the EM curve - more young adults at risk, lower costs of the move, more resources to finance the move, and more literate potential movers - contribute to an emigration boom, while a cessation in these forces, and wage catching up, contribute to an emigration bust.

\section{The Third World Emigration Life Cycle since the 1960s}

Pre-1914 mass migration without state intervention is one thing, but what about post-1970 mass migration under quotas and other restrictions? Here we focus on migrants from the three major developing regions: Latin America, including the Caribbean; the Middle East, North Africa and Asia; and Sub-Saharan Africa. We exclude from consideration the countries of the former Soviet Union and Eastern Europe as these are affected by the political regime change in the middle of the period. ${ }^{4}$ Table 1 shows for the five-year periods between $1970-4$ and $2000-4^{5}$ the immigration rates to the US (migrants relative to US population) and emigration rates (migrants relative to sourceregion population), with 1970-4 $=100$. Three things stand out in the upper two panels. First, immigration rates increase much more steeply than do emigration rates. The surge of migrants looks a lot more modest when standardized by the more rapidly-growing source populations. ${ }^{6}$ Second, emigration rates often tend to lead immigration rates: thus,

\footnotetext{
${ }^{3}$ Aging of the immigrant stock abroad may have the same effect as family and kin ties weaken with assimilation in the host country.

${ }^{4}$ We also exclude the poor counrties of Oceania where the numbers are miniscule.

${ }^{5}$ The migration rates are for fiscal years 1970/1-2004/5.

${ }^{6}$ It would look even more modest if the emigrants were included in the denominator, although the differences are slight.
} 
Asian emigration rates peaked a decade before immigration rates. Third, Asian emigration rates reached a peak in the 1980-84 while Latin American emigration rates reached a peak just a half decade later, in 1985-94. By contrast, the emigration rate from Sub-Saharan Africa continued to grow throughout the period.

The lower panel of Table 1 provides a more detailed breakdown for Latin America and Asia. It shows that the trend in Latin American emigration is not just due to Mexico (which accounted for about half of all US immigration from the Americas during the 1991-2000 decade, including Canada: Hatton and Williamson 2005: p. 208). Neither is it solely due to the legalization of undocumented migrants (principally from Mexico) that affected the figures in 1989-91. Emigration rates from the Caribbean, Central America and South America all have peak emigration rates in the decade 1985-94. The pattern for Asia is similar but a bit more mixed: North African and Middle Eastern (MENA) emigration rates underwent a pronounced decline after 1980-4; East Asian rates underwent a more modest decline after 1990-94; and the South Asian decline after 199094 was actually reversed in 2000-04.

These trends raise four questions. First, are they driven by a few countries with very large immigrant numbers that dominate the regional totals? Or, is there a distinct life cycle pattern in the emigration rates even if we give equal weight to each country? We investigate this possibility by regressing the log of emigration rates (to allow for differences in scaling) on time and time squared for all the countries in each regional sample over the seven five-year periods 1970-4 to 2000-4, using country fixed effects. Table 2 shows that for the 26 countries of Latin America and the Caribbean there is a significant inverted U with a maximum in the early 1990s. A similar (significant) life 
cycle pattern is found for 35 countries in the North Africa, the Middle East and Asia; the squared term is negative and the peak occurs in the early 1990s. By contrast, only the linear term is significant for Sub-Saharan Africa, the sending region containing the poorest countries. These results confirm a fall in emigration rates for two of the major sending regions, while the third has yet to reach its peak.

Second, is the fall in Third World emigration rates just for those going to the United States, or are the same effects observed for other immigrant host countries? Table 3 shows immigration and emigration rates to Canada and Germany from the three sending regions. ${ }^{7}$ The Latin American and Asian immigration rates for Canada have been falling since 1990-94, repeating the US pattern. This suggests that the slowdown and fall in immigration rates from the early 1990s is not just the result of US-specific policy changes. And, again repeating the US pattern, immigration rates from Africa and Asia rose much more steeply over the long term than did the emigration rates. Also, the emigration rates from Asia and Latin America into Canada have fallen more dramatically since 1990-94 than have immigration rates, as has been true of the US. Finally, the rise in the emigration rate to Canada from Africa, once again, was slower than for the immigration rate.

The lower panels of Table 3 document the immigration and emigration rates to Germany. These comparisons are complicated by German reunification in 1990 and the migration rates here are based on the combined population throughout. The German immigration rates display a strong upward trend to 1990-94, and a fall (or a pronounced

\footnotetext{
${ }^{7}$ Other host countries do not offer the kind of evidence necessary for the empirical analysis which follows.
} 
slowdown in the rise) thereafter. Once again, emigration rates show a more pronounced life cycle than do immigration rates. ${ }^{8}$

Third, are the recent downward trends or pronounced slowdowns in emigration rates simply due to tougher immigration policies in host countries rather than to declining emigration pressure in source regions? Imagine for a moment that the immigration rate reflects only policy and that policy has been aimed at stabilizing immigration relative to the home population. This implies that emigration rates from regions with rapidly growing populations should fall. Under such conditions, policy gets tougher, and all the more so if there are pressures pushing up source country emigration rates.

Finally, if emigration policy got tougher over time, did emigration pressure from sending countries create those policies? That is, can immigration policies in host countries be viewed as an endogenous political response to rising emigration pressure abroad? Perhaps, but it does not appear to have been the case that immigrants from Latin America, Asia and Africa have crowded out potential immigrants from other regions, an effect that would have eased any political pressure for tougher immigration restrictions. That is, while emigration from eastern Europe, southern Europe and the former Soviet Union fell as a proportion of US immigration from the 1960s to the 1980s, that share stabilized between the 1980s and 1990s. In any case, the central point is this: when analyzing trends in migration from any source region, overall host country policy constraints must be taken in to account. The empirical work that follows does just that.

\footnotetext{
${ }^{8}$ Note that both the immigration and the emigration rates from Turkey fall steeply from the end of the guestworker era after 1974.
} 


\section{Possible Causes of the Third World Emigration Life Cycle}

Here we focus on emigration rates to the United States from Latin America, Asia and Africa. After all, the US is home to more than half of the stock of inter-continental immigrants from these regions. US immigration offers the best opportunity to evaluate the longer term trends since its immigrants come from a wider variety of countries over a longer period than is true for most other host countries. Thus, we can include more source countries in the empirical analysis without having to place too much weight on migration streams that are small and volatile.

Our goal is to identify the source country economic and demographic fundamentals that drive emigration to the US. As in all migration models, the major determinant is income of the home country relative to US. However, the incentive to migrate does not depend just on income gaps, but also on the human capital of the potential migrant needed to exploit the gap. Therefore, we also include relative education, using average years of schooling in the home country relative to the US (Barro and Lee 2001). The positive effect of home country education that is often found in migration equations reflects the fact that higher home education for a given income level implies a lower rate of return to education at home. Alternatively, schooling in the home country gives the potential emigrant the credentials to take advantage of the higher relative income in the host country. ${ }^{9}$

\footnotetext{
${ }^{9}$ In any case, the result should not necessarily be interpreted as suggesting that the more educated have higher mobility.
} 
Two demographic fundamentals feature in most migration models. The first is the relative size of the migration intensive cohort, reflecting the fact that the net present value of a given income gap is higher for young adults. To measure this first demographic fundamental, we use the relative size of the cohort aged 0-14 fifteen years before the date of observation. ${ }^{10}$ The second key demographic fundamental is the stock of immigrants from the source country resident in the US. This measures the friends and relatives effect that is thought to diminish the cost and uncertainty of migration. Most studies find this effect to be powerful. Perhaps even more to the point, the friends and relatives effect should be all the more powerful in the presence of immigration policies that favor family reunification, as they do in the US. ${ }^{11}$ We measure the effect by dividing the US migrant stock from each source country by the source country population at the beginning of each five year period.

It is widely recognized that poverty acts as a constraint on migration owing to capital market imperfections. This constraint is especially important for long-distance moves as it is hard to raise a loan for an investment in a move which takes the borrower out of the lender's jurisdiction. Here we proxy the share of the population in poverty by a non-linear transformation of per capita income so that the poverty-reducing effects of an increase in income are more powerful at lower income levels. While poverty implies lower mobility, the poverty constraint is likely to be loosened by having friends and

\footnotetext{
${ }^{10}$ The size of the 0-14 age group lagged fifteen years is used rather than the current size of the 15-29 age group since the latter is likely to be diminished by (the predicted) high exit rates.

${ }^{11}$ The friends and relatives effect should be much more powerful for the US where family reunification policy has always been more generous. Family reunification could also weaken the role of young adult cohort size in pushing emigrants out of sending countries. This prediction could be explored by a comparison of emigration rates to the US with that of other host countries, an issue not explored here or, as far as we know, elsewhere in the literature.
} 
relatives at the destination: hence, the larger the migrant stock in the host country, the less the poverty constraint facing potential emigrants.

Finally, and as noted earlier, immigration policies must be considered in the analysis. If immigration policies have become tougher since the early 1990s, then this fact could account for the slow down or decline in emigration rates in recent years. One way of taking host country policy into account is to include period fixed effects which should capture any common trends in migration across different source countries, like host country policy. An alternative approach is to include a measure of the overall immigration quota in the analysis: here, policy 'toughness' is measured as the total US immigration quota relative to the population of all three sending regions (see Appendix). We much prefer the quota-based measure, but we will try both in the analysis.

\section{Explaining Third World Emigration to the United States 1970-2005}

Table 4 presents the results of regressions for emigration rates to the US from 62 countries in Latin America, Asia and Africa (see Appendix). We use a balanced panel, 24 of the countries in Latin America and the Caribbean, 25 in Asia, the Middle East and North Africa, and 13 in sub-Saharan Africa. The African sample is limited by the data both for migration and for the explanatory variables. The dependent variable is the log of five-year total emigration rates for fiscal years (e.g. 1970-4 includes the fiscal years 1970/1 to 1974/5), while all explanatory variables are for the beginning of the five year period (e.g. 1970, 1975). Fixed country effects ensure that we focus on the trends over time, absorbing in the fixed effects variables such as distance between the source country 
and the US, whether the source country is English speaking, and cultural affinities between the two.

The column (1) regression includes five-year period dummies which capture changing immigration policies and any other trends, such as falling migration costs and information diffusion that would be common to all source countries. The cohort effect is the right sign but not significant in this regression. However, the income ratio and the education ratio are strongly significant with the expected signs. Furthermore, the two estimated coefficients are of a similar magnitude, supporting the view that relative income and relative education should have equal and opposite effects. The log ratio of the emigrant stock to source country population is strongly positive, reflecting the power of the friends and relatives effect, enhanced by the immigration policy filter. While the effect of poverty is negative as predicted, it is attenuated by an increase in the emigrant stock, also as predicted.

The column (2) regression replaces the period dummies with our preferred immigration policy constraint variable. Controlling for the policy environment properly serves to increase the size and significance of the cohort size coefficient and to reduce the size of the still-significant relative income and relative education coefficients. The effect of a one percentage point increase in the size of the migration-sensitive cohort in the source country increases emigration to the US by about 2.4 percent. This effect is largeat the sample averages it implies an increase in five-year emigration rates of about 3 per thousand of the source population between the early 1970s and the early 1990s. The effect of the migrant stock is also large: an increase of one percent in the US source country migrant stock increases the emigration rate by about 0.32 percent. At the sample 
means (including the interaction with poverty), this implies a chain migration effect where for every 1000 of the stock of previous migrants a further 90 would arrive in the following five-year period, or 18 each year. That figure was much the same in the $19^{\text {th }}$ century (20 each year: Hatton and Williamson 2005, p. 65), and, as we shall see, this has important implications for the dynamics of migration since it means that migration streams persist long after the original shocks that created them.

The effect of source country poverty is of special interest. Excluding the interaction with the migrant stock, a doubling in per capita income from US\$1,000 to \$2,000 (about equivalent to the East and Southeast Asian per capita income level in 1960 and its growth rate between 1960 and 1985, 3.4 percent: Maddison 2008) increases the emigration rate by 12 percent. In contrast, an increase for today's middle income country from $\$ 10,000$ to $\$ 11,000$ has a negligible effect on the emigration rate ( 0.03 percent). To see more clearly how the poverty-constraint-eradication effect contributes to the emigration life cycle, note that a 50 percent increase in per capita income at $\$ 1000$ raises the emigration rate by 9 percent while the same percentage increase at $\$ 10,000$ raises the emigration rate by just 0.1 percent. That is, the poverty effect is non-linear, powerful at low-income levels and weak at middle-income levels. Thus, the poverty effect by itself can produce the emigration life cycle.

But there are two forces that tend to offset the poverty constraint. The first offset operates through the relative income gap. With no change income at the destination and no change in relative education, a 50 percent increase in per capita income from $\$ 1,000$ reduces emigration by 12 percent—exactly offsetting the poverty effect. However, if per capita income growth at home is positive but does not exceed that of the US, then 
emigration pressure rises. The second effect can occur through the interaction with the migrant stock. For example, when a country with a migrant stock abroad equivalent to 10 per thousand of the home population enjoys an increase in per capita income from $\$ 1000$ to $\$ 2000$, the emigration rate increases by just 1.3 percent, as compared with a 12 percent increase for a country with zero migrant stock (i.e. no emigration history). Thus for poor countries, a large migrant stock in the host country can largely eliminate the poverty constraint, as it did for the Irish in the $19^{\text {th }}$ century.

The regressions in columns (3) and (4) explore the result when the interaction between the poverty proxy and the migrant stock is omitted. It matters. In column (3), the poverty effect is now negligible, which highlights the importance of the friends and relatives effect in releasing the poverty constraint. Column (4) shows that in the absence of the migrant stock the effect of the coefficients on relative income and relative education increase dramatically. This is because the migrant stock reflects past immigration, which in turn depends on past gaps in relative income and relative education that persist to the present. In effect, without the migrant stock, economic fundamentals matter much more since migrants tend to be driven by job opportunities rather than family ties.

\section{Decomposing the Sources of Trends in Third World Emigration Rates}

This section explores emigration rate trends by source region to see how the fundamentals that determine emigration (Table 4) influenced long term trends. Table 5 compares actual log emigration rates with predicted rates in our balanced panel for each 
of the seven five-year periods, both expressed as deviations from the overall 1970-2004 mean for the source region. The patterns observed for these mean deviations do not exactly replicate Tables 1 and 2 since they are estimated with a smaller sample of source countries. Nevertheless, the patterns are certainly consistent.

The actual or observed mean deviation for Latin America and the Caribbean rises from 36 log points below the average in 1970-4 to 31 log points above the average in 1985-9 before falling close to the mean in 2000-4. The predicted values rise from 44 log points below the average in 1970-4 to a plateau of 22 log points above the average from 1985-9 onwards. For the Asia, Middle East and North Africa region, there is a steep increase in observed mean deviations from -39 log points in 1970-4 to a peak of 26 log points in 1990-4 followed by a decline to 16 log points in 2000-4. The predicted values yield a similar profile, although the predicted peak occurs in 1985-9 rather than 1990-4. As was found in Table 2, the trajectory for sub-Saharan Africa is a fairly linear upward trend. This is evident in both the actual and predicted series although it is stronger in the former.

Two questions naturally follow. The first, which we pursue here, is this: How do the underlying explanatory variables account for these emigration trends in the source regions? We save the second for the next section: What happens to the Third World emigration rate when the explanatory variables are projected into the future? In order to examine the contributions of the different variables we multiply the change in the explanatory variable by its coefficient in column 2 of Table 4 . Table 6 reports the decomposition for changes in the emigration rates in log points. For Latin America and the Caribbean and for Asia, the Middle East and North Africa we distinguish between the 
upswing from 1970-4 to 1990-4 and the subsequent decade whereas for sub-Saharan Africa we take the three decades as a whole.

In all three sending regions, the migrant stock effect made the most important contribution to the emigration rate boom, reflecting the importance of family reunification in US immigration policy. Yet, there is another way of interpreting the migration stock effect: it has embedded in it the impact of all these fundamentals which, in the past, brought the primary family mover to the United States. Thus, consider the share each fundamental contributed to the residual difference between all effects up to peak and that of the migrant stock (e.g. 0.60-0.38 $=0.22$ for Latin America and the Caribbean). Using this accounting, here are the contributions of the key fundamentals in percent for Latin America and Africa: Latin America, income gap 36, birth cohort 32, education gap 22, and poverty 0; Africa, income gap 70, education gap 28, birth cohort 20, and poverty -20. Asia is especially interesting. Were it not for the migrant stock effect, Asian emigration rates would have fallen between 1970-4 and 1990-4 (0.50-0.87 = -0.37), and almost all of that was being driven by education gap catch up (education gap 89 percent) and income catch up (income gap 16 percent).

\section{What Will Third World Emigration Rates Look Like in the Future?}

What should we assume about host country policy when we project the future? Clearly immigration policy has important effects on the numbers who are able to emigrate to the United States. Recall that our measure of the overall immigration constraint is the total US quota divided by the total population of the three sending 
regions for each five year period. While the overall quota trended upward, so did the population of the three sending regions. As it turns out, there has been no change in the US policy constraint since 1970, at least as we have defined it. ${ }^{12}$ Thus, the projections will assume that there will be neither tightening nor loosening in the immigration constraint in the near future.

To examine the underlying trends in the explanatory variables by sending region, in our balanced panel they are regressed on a quadratic in time, with country fixed effects. We have observations for each of the explanatory variables on most of the countries back to 1960. The demographic projection (which involves a lagged variable) relies on the UN's estimates up to 2020. The squared term is dropped where it is insignificant. The results are provided in Table 7.

The size of the relevant birth cohort follows a strong quadratic inverse U shape trend for all three sending regions. The birth cohort variable trend peaks is in the late 1980s for Latin America and Asia, while that for sub-Saharan reaches a peak around 2000. In contrast, the relative income and relative education trends are uniformly linear. Latin America exhibits some falling behind in income per capita relative to the US (the positive coefficient 0.0603 implying a rise in the income gap), but some catching up in relative education (the negative coefficient -0.048 implying a fall in the education gap) . Sub-Saharan Africa fell further behind in relative income even more than Latin America but exhibited even greater catching up in relative education. The trend in poverty has been clearly downwards in Latin America, and even more so in Asia, although in both

\footnotetext{
${ }^{12}$ Our measure of policy exhibits an inverse $U$ shaped trend that is almost entirely the result of the legalization program under the Immigration Reform and Control Act of 1986 that resulted in a large increase in recorded migration in 1989-91, most of which came from Mexico. If we exclude this component of the policy index then there is no evidence of a trend. When this modified version of log policy is regressed on a trend the coefficient is -0.011 , with a ' $t$ ' value of 0.51 .
} 
cases it flattens out as would be expected given the functional form of the poverty variable. Sub-Saharan Africa's poor economic performance is reflected by a linear upward trend. ${ }^{13}$

The projected emigration rates are derived using the quadratic or linear trend in the fundamentals as reported in Table 7. The trends in these variables will have a cumulative effect on emigration rates since they affect the host country migrant stock in successive periods, thus influencing future emigration rates. For each of the fundamentals in Table 7, we calculate the effect of the change on emigration rates in each period but we also take account of the effect on the migrant stock in subsequent periods. Thus, the simulation updates the migrant stock in each period and adds the indirect effects on emigration through the migrant stock (including its interaction with poverty) to the direct effect in the subsequent period. Table 8 reports the overall difference in log points between the simulated emigration rate in 2020-4 and in the base period 2000-4. These are averages for the individual countries in each regional group.

For Latin America and Asia, demographic pressures are predicted to reduce emigration rates by 21-22 log points on average. These demographic forces will dominate trends in emigration rates in the future since no other fundamental will do anywhere near the work that this one will in these two regions. However, the combined effects of relative income and relative education partially offset the effect of demographic trends: the two combined increase emigration rates by $12 \log$ points in Latin America and $8 \log$ points in Asia. Sub-Saharan Africa offers a sharp contrast: the demographic effects are negative but small, while the relative income and relative education effects are both

\footnotetext{
${ }^{13}$ Note, however, that the level of significance $(t=1.78)$ is lower for sub-Saharan Africa, reflecting the large variance in economic performance across the region.
} 
positive, adding up to a powerful 30 log points. The effects of rising poverty (including the interaction with the migrant stock) are neutral for Latin America -- where the poverty constraint is less binding, and positive for Asia - where poverty more binding but is being quickly eroded. Poverty is projected to increase in sub-Saharan Africa and its impact tends to reduce emigration rates powerfully (larger than the birth cohort or income gap effect): the effects are negative as the direct effect of deepening poverty outweighs the interaction with the migrant stock.

The penultimate row in Table 8 shows the independent effect of the migrant stock. This arises because migrant stocks are projected to increase even in the absence of any further 'push' from the other emigration fundamentals. The higher is current emigrant flow relative to the previous migration stock, the greater is the rate of increase of the stock, which in turn boosts emigration rates in the next period. These migrant stock dynamics produce effects that persist into the future at different rates for different source regions. For the Latin American countries, where the current migrant stock is relatively high relative to the flow, the stock dynamics have no effect (0 log points). For the Asia and MENA countries, where the current migrant stock is lower, dynamics increase the emigration rate by 8 log points between 2000-4 and 2020-4. The most striking result, however, is for sub-Saharan Africa, where the migrant stock is low relative to the current flow: in this case, stock dynamics are projected to increase the emigration rate by an enormous $21 \log$ points.

Adding these effects together, the overall projection implies a decline in the emigration rate from Latin America and the Caribbean, and a stable emigration rate from Asia, the Middle East and North Africa. Sub-Saharan Africa, on the other hand, is 
projected to undergo a steep increase of 19 log points in its emigration rate, driven by rising income gaps, falling education gaps and migrant stock dynamics. When the three regions are weighted by shares in total US immigration, the projected result is a modest fall of $1.8 \log$ points in the overall emigration rate. Alternatively, when they are weighted by sending region populations, the result is a modest increase of $2.7 \log$ points. When we look beyond 2024, the migrant stock dynamics weaken and the continued fall in the other fundamentals will almost certainly cause Third World emigration rates to fall.

In contrast with media hysteria and academic assumption, these results strongly support the view that there will be no mounting emigration pressure from the Third World over the next two decades, and a likely fall thereafter. Of course, if Africa starts to register double digit GDP per capita growth rates, the fall in emigration rates may be postponed as unlocking the poverty trap will dominate before the effect of reduction in the income gap takes over.

\section{Why Did Third World Emigration Wait Until After the 1960s?}

Why didn't the Third World post-war emigration boom start in the late 1940s, the 1950s or the 1960s? After all, the income gap between industrial and Third World countries was huge. Why did the boom wait until the 1970s? Now that we have analyzed the Third World emigration life cycle over the half century 1970-2024, the answers should be clearer. Four fundamental forces emerged simultaneously, and all four underwent dramatic change between the 1950s and 1970s: 
Leveling the policy playing field: From the Emergency Quota Act of 1921 until the Immigration and Nationality Act of 1965 (which became effective in mid-1968), the US applied strict country of origin quotas that were related to the stock of foreign-born in the US population before the First World War. The 1965 Act replaced this regime with a non-discriminatory policy under which migrants from all countries could compete equally for immigration into the US, ${ }^{14}$ first under separate quotas for the Eastern and Western Hemispheres and then under a combined worldwide quota after $1979 .{ }^{15}$ The new policy regime also greatly favored immigrants arriving by family reunification, most of whom did not even fall under the quota.

The composition of US immigrants by source changed dramatically between the 1950s and the 1970s. The European, Canadian and Oceanic share fell by about 45 percentage points, and the Third World share rose by 55 percentage points, the rise for Asia by itself 29 percentage points (Hatton and Williamson 2005: Table 10.2). Policy reform certainly opened up opportunities for migrants from poor countries, but dramatic changes on the supply side transformed the benign policy regime into a surge of migration.

Third World schooling revolutions started reducing the education gap: A revolution in primary schooling and literacy took place in the Third World prior to the emigration boom (Easterlin 1981; Schultz 1987), and it started to erase the education gap between the US and sending countries. Between 1960 and 1981 the ratio of expected years of schooling in industrial countries relative to low-income countries fell from 1.92 to 1.60 ,

\footnotetext{
${ }^{14}$ Non-discriminatory immigration policies were enacted a little later by Canada, Australia and New Zealand.

${ }^{15}$ Before 1979 the overall quota for the Eastern Hemisphere was 170,000 per annum; for the Western Hemisphere it was 120,000 until 1976 and then 88,800 for 1977-78.
} 
and the same ratio relative to middle income oil importers fell from 1.82 to 1.44

(Williamson 1993: Table 4.8). Between 1960 and 1987, the education stock (school years per person ages 15-64: Nehru et al. 1995: Table 1) rose by only 0.3 percent per annum in the industrial countries, but by 4 percent in the developing world. Based on our model and the countries in our sample, the direct effects of those trends would have been to increase emigration rates from Latin America and the Caribbean by 5 log points between 1950-4 and 1970-4, by 10 log points from Asia, the Middle East and North Africa, and by $8 \log$ points for Sub-Saharan Africa.

Growth miracles started unlocking the poverty trap: Not many Third World regions started catching up with the industrial world like the East Asian gang of four did, but per capita incomes did rise enough to start unlocking Third World poverty traps. Between 1950 and 1970, per capita income rose by 52 percent in Africa, by 41 percent in East Asia, by 59 percent in Latin America, and - pulled by oil - by 125 percent in the Middle East (Maddison 2008). The direct effects of unlocking the poverty trap would have added $10 \log$ points to the emigration rate from Asia between 1950-4 and 1970-4.

Demographic transitions began to yield fat young adult cohorts: The timing of the demographic transition in the Third World mattered. The share of Asia's population aged 0-14 started rising rapidly in the 1950s, with the result that the migration-sensitive age group rose sharply in the 1970s and 1980s. The share of the working age population in Asia rose dramatically after it bottomed out in the late 1960s, and other sending regions followed. For example, the East Asian adult percent share rose from about 57 in 1965 to 67 in 1995 (ADB 1997: Figure 3.4). Based on our model, the direct effects of the demographic transition would have added a huge 20 log points to emigration rates from 
Latin America and the Caribbean and from Asia, the Middle East and North Africa from 1950-4 to 1970-4. Demographic pressures increased a little later in sub-Saharan Africa but they still would have added about 16 log points to the migration rate between 1950-4 and 1970-4.

What would have happened if the US Congress had passed those Amendments to the US Immigration Act in 1950 rather than 1965? Emigration pressures stemming from the key fundamentals were much lower in 1950 but by the 1960s they were building up. Most importantly, the stock of migrants from the Third World was relatively low in 1950 partly because emigration pressures were modest and partly because of discriminatory policies, like the Asiatic Barred Zone which prohibited Asian immigration from 1917 to 1952. This suggests that emigration from Asia would have surged in the 1960s rather than in the 1970s when its share in total US immigration increased from 12.9 percent in 1961-9 to 35.3 percent in 1971-9 (Hatton and Williamson 2005, p. 208). In Latin America, emigration pressures were building up more slowly, policy was much less restrictive, and there was already a substantial migrant stock. As a result, the emigration rate rose only modestly between the 1960s and the 1970s. Finally, emigration from Africa was very small in the 1950s as Africans were constrained both by colonialism and poverty. Although migration from Africa rose continuously, the base was very small and the increase was driven almost entirely by the migrant stock.

\section{Host Country Implications}

This paper has argued that to understand the forces that drive international migration we must take a source country perspective. Only then can we assess the 
fundamental forces that have underpinned the ebb and flow of migration over the last half century that will drive migration in the future. Much of literature, however, takes a host country perspective and its agenda is often determined by host country concerns about rising migration pressure leading to soaring immigration rates. What do we find when we look instead at the supply side, using the United States as our window on the process?

Trends in migration rates are very different when viewed from a source country perspective. Since the Second World War, population growth rates have been higher and fell later in poor sending countries compared with rich host countries where they have been lower and fell sooner. This has served to influence the timing and magnitude of the migration rates: emigration rates have tended to lead immigration rates, but they have been less dramatic.

These trends in late $20^{\text {th }}$ century Third World emigration rates trace out country and region life cycles, and the underlying fundamentals can be identified. First, the US migrant stock effect made the most important contribution to the boom up to the 1990s, reflecting both the importance of family reunification in US immigration policy and that the impact of previous changes in the economic and demographic fundamentals got embedded in the current migrant stock. Indeed, were it not for the migrant stock effect, Asian emigration rates would have fallen after 1970-74, rather than rising to 1980-4. The change in the poverty trap mattered only for Africa, where a rise in poverty rates reduced emigration rates over time. Education catch up played an important role everywhere in the Third World, augmenting emigration rates. The birth cohort effect also played an important role in Latin America and Africa, but not in Asia (where much of the demographic transition had already run its course by the 1970s). While there was 
certainly per capita income growth in Asia and Latin America, it was not fast enough to reduce the income gap with the US, and thus it contributed a little to the emigration boom. For Africa, however, it contributed a lot, as poor growth performance caused Africa to lose ground and the income gap to rise.

Having estimated the causes of the Third World emigration rates over the past half century, we turned to projections of the future. These projections speak to a changing composition of US immigration by source and its total size. In 2000-4, the US immigration shares (of the three region total) were 41 percent from Latin America and the Caribbean, 53 percent from Asia, North Africa and the Middle East, and 6 percent from Sub-Saharan Africa. By 2020-4, the share from Latin America and the Caribbean is projected to fall to 38 percent while the share from Asia, the Middle East and North Africa will decrease modestly to 52 percent. The most striking change is the rise in the share from sub-Saharan Africa from 6 to 10 percent, a significant increase in the share of Africans. In short, US immigrants will be more African and less Hispanic fifteen or twenty years for now.

A final observation is this. History demonstrates that migration stock dynamics are important. During the transatlantic migrations of the late $19^{\text {th }}$ century, for each thousand of the migrant stock 20 more migrants were pulled across the Atlantic each year (Hatton and Williamson 2005, p. 65). That $19^{\text {th }}$ century figure is close to the late $20^{\text {th }}$ century 18 per thousand estimate obtained here. The 'friends and relatives effect' was particularly strong in the upswing of every sending region emigration cycle, first for Latin American emigrants, a little later for Asian emigrants, and most recently (and in the future) for the Africans. While the migrant stock effects tend to fade over time, they 
nevertheless cause migration rates to persist long after the other fundamentals have turned down. This is an important reason why the impending decline in Third World emigration rates has been obscured from view. 


\section{References}

Asian Development Bank [ADB] (1997), Emerging Asia: Changes and Challenges (Manila, The Philippines).

Barro, R. J. and J-W. Lee (2001), “International Data on Educational Attainment: Updates and Implications,” Oxford Economic Papers 53: 541-63.

Clark, X., T. J. Hatton and J. G. Williamson (2007), “Explaining US Immigration 19711998,” Review of Economics and Statistics 89 (May): 335-42.

Easterlin, R. A. (1981), "Why Isn't the Whole World Developed?" Journal of Economic History 41: 1-19.

Gould, J. D. (1979), "European Inter-continental Emigration, 1815-1914: Patterns and Causes," Journal of European Economic History 8: 593-679.

Hatton, T. J. and J. G. Williamson (1994), "What Drove the Mass Migrations from Europe in the Late Nineteenth Century?" Population and Development Review 20: $1-27$.

--- (1998), The Age of Mass Migration: An Economic Analysis (New York: Oxford University Press).

---(2003), “Economic and Demographic Pressure on Emigration Out of Africa,” Scandinavian Journal of Economics, 105: 465-486.

--- (2005), Global Migration and the World Economy: Two Centuries of Policy and Performance (Cambridge, Mass.: MIT Press).

Kirk, D. (1946), Europe's Population in the Interwar Years (Princeton, NJ: Princeton University Press for the League of Nations). 
Maddison, A. (2008), Statistics on World Population, GDP and Per Capita GDP, 12006AD at www.ggdc.net/Maddison.

Nehru, V., E. Swanson, and A. Dubey (1995), “A new database on human capital stock in developing and industrial countries: Sources, methodology, and results,” Journal of Development Economics 46: 379-401.

Pritchett, L. (2006), Let Their People Come: Breaking the Gridlock on Global Labor Mobility (Washington, D.C.: Center for Global Development).

Schultz, T. P. (1987), "School Expenditures and Enrollments, 1960-80: The Effects of Income, Prices, and Population Growth,” in D. G. Johnson and R. D. Lee (eds.), Population Growth and Economic Development: Issues and Evidence (Madison, Wis.: University of Wisconsin Press): 413-76.

Williamson, J. G. (1993), “Human Capital Deepening, Inequality, and Demographic Events along the Asia-Pacific Rim,” in N. Ogawa et al. (eds.), Human Resources in Development along the Asia-Pacific Rim (Singapore: Oxford University Press): $129-58$.

Williamson, J. G. (2001), “Demographic Shocks and Global Factor Flows,” in J. N. Little and R. K. Triest (eds.), Seismic Shifts: The Economic Impact of Demographic Change (Boston, Mass.: Federal Reserve Bank of Boston, Conference Series No. 46: 247-69.

Williamson, J. G. (2007), “Inequality and Schooling Responses to Globalization Forces: Lessons from History,” in Migration, Trade and Development (Dallas, Texas: Dallas Federal Reserve Bank). 


\section{Data Appendix}

\section{Countries included in Regression Analysis}

\begin{tabular}{|l|l|l|l|}
\hline \multicolumn{4}{|l|}{ Latin America and the Caribbean } \\
\hline Argentina & Costa Rica & Haiti & Paraguay \\
\hline Barbados & Cuba & Honduras & Peru \\
\hline Bolivia & Dominican Republic & Jamaica & Suriname \\
\hline Brazil & Ecuador & Mexico & Trinidad \& Tobago \\
\hline Chile & El Salvador & Nicaragua & Uruguay \\
\hline Colombia & Guatemala & Panama & Venezuela \\
\hline Asia, Middle East and North Africa & \multicolumn{5}{|l|}{} \\
\hline Afghanistan & India & Kuwait & Syria \\
\hline Algeria & Indonesia & Malaysia & Thailand \\
\hline Bangladesh & Iran & Nepal & Tunisia \\
\hline China & Iraq & Pakistan & Turkey \\
\hline Cyprus & Israel & Philippines & \\
\hline Egypt & Jordan & Singapore & \\
\hline Hong Kong & Korea & Sri Lanka & \\
\hline Sub-Saharan Africa & \multicolumn{5}{|l|}{} \\
\hline Cameroon & Liberia & Sudan & Zimbabwe \\
\hline Dem. Rep. Congo & Senegal & Tanzania & \\
\hline Ghana & Sierra Leone & Uganda & \\
\hline Kenya & South Africa & Zambia & \\
\hline
\end{tabular}

\section{Data Sources}

Immigration to USA: Five-year total immigration to the United States by country of birth is taken from the Department of Homeland Security, Yearbook of Immigration Statistics (before 2002 entitled the Statistical Yearbook of the Immigration and Naturalization Service). Five year totals calculated from annual data, with an adjustment to the years 1976 and earlier for the change in the fiscal year. The country of origin classification used here is country of birth rather than country of last residence. This ensures consistency with the immigrant flow and the immigrant stock as measured in the census.

Immigrant stock in the US: Foreign born stock data for the census years 1970, 1980 and 1990 are taken from C. J. Gibson and E. Lennon (1999), "Historical Census Statistics on the Foreign-born Population of the United States, 1850-1990,” US Census Bureau Population Division, Technical Working Paper No. 29. Data for 2000 were obtained from the 2000 US Census. The intervening years 1975, 1985 and 1995 using the stock accumulation equation $S_{t+1}=(1-d) S_{t}+M_{t}$ where $M$ is the migrant inflow, $\mathrm{S}$ is the migrant stock and $\mathrm{d}$ is the 'depreciation ' rate calculated for each intercensal period.

Source country population: Total population and share aged 0-14 taken from United Nations (2007), “World Population Prospects: the 2006 Revision” (CD ROM).

Years of education: Average years of education for the population age 15 and over, at five-year intervals from the database of Barro and Lee, available at: http://www2.cid.harvard.edu. 
Income per capita: Income per capita at constant 2000 prices (chain series) for years ending in 0 and 5 from A. Heston, R. Summers and B. Aten, Penn World Table 6.2, University of Pennsylvania, Center for International Comparisons of Production Income and Prices, available at: http://pwt.econ.upenn.edu/php_site/pwt_index.php.

US immigration policy: The immigration policy constraint is modeled as the number of immigrants coming under the overall quota. These include non-immediate relatives, employment visas, diversity immigrants, refugees and asylees, and those admitted under the Immigration Reform and Control Act (1986). We take the effect of IRCA to be an increase in immigration of 2.7 million spread over the three years 1989-1991. This measure of the overall quota is applied to all countries, rather than being tailored to each country. It amounts to two thirds of total immigration between 1970 and 2005, with the other third accounted for by those family-reunified migrants that do not fall under the US quota. The calculation of these categories is discussed in full in Clark et al. (2007). The total of these categories for each five-year period is expressed per thousand of the population in the three world regions at the beginning of the period. 
Table 1

Immigration and Emigration Rates to the US from Source Regions

\begin{tabular}{|c|c|c|c|c|c|c|c|}
\hline Years & $1970-4$ & $1975-9$ & $1980-4$ & $1985-9$ & $1990-4$ & $1995-9$ & $2000-4$ \\
\hline & \multicolumn{7}{|c|}{ Immigration Rates } \\
\hline Latin Am \& Carib & 100.00 & 116.19 & 113.82 & 267.96 & 273.01 & 169.01 & 186.76 \\
\hline Sub-Saharan Africa & 100.00 & 190.59 & 242.64 & 380.39 & 489.00 & 700.78 & 840.47 \\
\hline \multirow[t]{2}{*}{ Asia (inc MENA) } & 100.00 & 150.24 & 192.58 & 190.97 & 207.89 & 154.69 & 179.42 \\
\hline & \multicolumn{7}{|c|}{ Emigration Rates } \\
\hline Latin Am \& Carib & 100.00 & 107.24 & 98.09 & 218.51 & 212.08 & 126.77 & 136.48 \\
\hline S-S Africa & 100.00 & 174.50 & 201.02 & 286.67 & 336.88 & 446.01 & 498.02 \\
\hline \multirow[t]{2}{*}{ Asia (inc MENA) } & 100.00 & 142.45 & 197.48 & 165.68 & 150.27 & 93.25 & 91.81 \\
\hline & \multicolumn{7}{|c|}{ Immigration Rates } \\
\hline Mexico & 100.00 & 90.88 & 95.41 & 356.58 & 382.82 & 185.99 & 205.67 \\
\hline Central America & 100.00 & 182.07 & 248.35 & 665.26 & 569.31 & 417.81 & 559.17 \\
\hline Caribbean & 100.00 & 119.95 & 99.43 & 137.88 & 137.58 & 110.55 & 102.51 \\
\hline S. America & 100.00 & 155.16 & 157.43 & 221.16 & 218.23 & 188.74 & 226.39 \\
\hline S-S Africa & 100.00 & 190.59 & 242.64 & 380.39 & 489.00 & 700.78 & 840.47 \\
\hline S. Asia & 100.00 & 132.54 & 167.32 & 200.13 & 271.52 & 269.46 & 349.66 \\
\hline MENA & 100.00 & 200.89 & 301.80 & 256.40 & 274.68 & 158.41 & 171.20 \\
\hline \multirow[t]{2}{*}{ E. Asia } & 100.00 & 118.76 & 123.88 & 131.14 & 132.89 & 104.86 & 125.67 \\
\hline & \multicolumn{7}{|c|}{ Emigration Rates } \\
\hline Mexico & 100.00 & 81.29 & 77.99 & 274.27 & 279.54 & 130.55 & 140.65 \\
\hline Central America & 100.00 & 164.99 & 204.99 & 515.90 & 409.47 & 279.47 & 350.01 \\
\hline Caribbean & 100.00 & 115.47 & 94.32 & 128.30 & 125.32 & 100.38 & 93.35 \\
\hline S. America & 100.00 & 144.01 & 136.80 & 181.62 & 170.88 & 142.97 & 167.35 \\
\hline S-S Africa & 100.00 & 174.50 & 201.02 & 286.67 & 336.88 & 446.01 & 498.02 \\
\hline S. Asia & 100.00 & 123.92 & 147.28 & 166.50 & 214.38 & 203.87 & 255.01 \\
\hline MENA & 100.00 & 187.42 & 263.54 & 212.70 & 217.74 & 121.08 & 126.90 \\
\hline E. Asia & 100.00 & 111.82 & 114.23 & 119.21 & 118.33 & 93.36 & 112.91 \\
\hline
\end{tabular}


Table 2

Time Trends in Log Migration Rates to the US

\begin{tabular}{|c|c|c|c|}
\hline & $\begin{array}{l}\text { Latin America and } \\
\text { Caribbean }\end{array}$ & $\begin{array}{l}\text { Asia, Middle East } \\
\text { and North Africa }\end{array}$ & Sub-Saharan Africa \\
\hline Constant & $\begin{array}{r}0.587 \\
(5.00)\end{array}$ & $\begin{array}{r}-1.719 \\
(10.83)\end{array}$ & $\begin{array}{r}0.394 \\
(21.62)\end{array}$ \\
\hline Time & $\begin{array}{r}0.379 \\
(5.63)\end{array}$ & $\begin{array}{r}0.496 \\
(5.45)\end{array}$ & $\begin{array}{r}0.245 \\
(2.36) \\
\end{array}$ \\
\hline Time Squared & $\begin{array}{r}-0.039 \\
(4.77)\end{array}$ & $\begin{array}{r}-0.050 \\
(4.51)\end{array}$ & $\begin{array}{l}0.006 \\
(0.50)\end{array}$ \\
\hline $\mathrm{R}^{2}$ (within) & 0.217 & 0.177 & 0.449 \\
\hline Countries & 26 & 35 & 38 \\
\hline Observations & 182 & 245 & 266 \\
\hline
\end{tabular}

Notes: The dependent variable is the five year total immigration from a source country divided by the initial year source country population. The time variable is scaled so that $1970-4=1, \ldots, 2000-4=7$.

Table 3

Immigration and Emigration Rates to Canada and Germany from Source Regions

\begin{tabular}{|l|r|r|r|r|r|r|r|r|}
\hline & $1970-4$ & $1975-9$ & $1980-4$ & $1985-9$ & $1990-4$ & $1995-9$ & $2000-4$ \\
\hline & \multicolumn{7}{|c|}{ Immigration Rates to Canada } \\
\hline Latin America & 100.00 & 87.43 & 57.28 & 80.24 & 103.28 & 52.43 & 57.80 \\
\hline Africa & 100.00 & 129.75 & 82.84 & 129.55 & 243.66 & 215.83 & 313.02 \\
\hline Asia & 100.00 & 111.21 & 125.29 & 156.87 & 293.86 & 259.37 & 276.49 \\
\hline & \multicolumn{7}{|c|}{ Emigration Rates to Canada } \\
\hline Latin America & 100.00 & 88.77 & 58.69 & 82.32 & 107.35 & 54.69 & 59.90 \\
\hline Africa & 100.00 & 120.90 & 70.98 & 101.28 & 181.07 & 149.37 & 201.28 \\
\hline Asia & 100.00 & 105.90 & 114.79 & 137.89 & 256.46 & 221.16 & 230.31 \\
\hline & \multicolumn{7}{|c|}{ Immigration Rates to Germany } \\
\hline Latin America & 100.00 & 85.35 & 82.59 & 110.36 & 120.73 & 115.43 & 126.99 \\
\hline Africa & 100.00 & 95.92 & 114.55 & 138.52 & 266.90 & 179.87 & 191.21 \\
\hline Asia & 100.00 & 158.49 & 201.65 & 268.77 & 323.98 & 300.91 & 369.94 \\
\hline Turkey & 100.00 & 64.62 & 41.95 & 36.45 & 37.71 & 29.04 & 25.65 \\
\hline & \multicolumn{7}{|c|}{ Emigration Rates to Germany } \\
\hline Latin America & 100.00 & 81.85 & 75.08 & 94.55 & 101.38 & 94.48 & 98.51 \\
\hline Africa & 100.00 & 84.41 & 87.07 & 90.43 & 160.24 & 97.69 & 92.04 \\
\hline Asia & 100.00 & 142.54 & 163.90 & 197.31 & 228.42 & 201.36 & 230.66 \\
\hline Turkey & 100.00 & 57.14 & 32.85 & 25.15 & 24.96 & 18.12 & 14.77 \\
\hline
\end{tabular}


Table 4

Determinants of Emigration Rates over 5 Year Periods 1970-4 to 2000-4 (Fixed effects, 62 countries)

\begin{tabular}{|l|r|r|r|r|}
\hline & $(1)$ & $(2)$ & $(3)$ & $(4)$ \\
\hline Constant & -0.974 & 0.683 & 0.646 & 0.115 \\
& $(1.97)$ & $(0.68)$ & $(0.68)$ & $(1.08)$ \\
\hline Birth cohort: population share aged 0- & 0.595 & 2.419 & 2.685 & 2.210 \\
14 fifteen years earlier. & $(0.53)$ & $(2.38)$ & $(2.63)$ & $(2.00)$ \\
\hline Log ratio of GDP per capita, US to & 0.417 & 0.296 & 0.231 & 0.427 \\
source country & $(4.41)$ & $(3.42)$ & $(2.63)$ & $(4.66)$ \\
\hline Log ratio of average years of education, & -0.506 & -0.258 & -0.264 & -0.759 \\
US to source country & $(3.87)$ & $(2.21)$ & $(2.24)$ & $(6.87)$ \\
\hline Log emigrant stock to source country & 0.449 & 0.316 & 0.334 & \\
population & $(7.54)$ & $(7.73)$ & $(8.26)$ & \\
\hline Poverty proxy: 100,000/(source & -1.700 & -1.631 & -0.129 & -0.175 \\
country GDP per capita) ${ }^{2}$ & $(3.04)$ & $(2.84)$ & $(0.84)$ & $(1.05)$ \\
\hline Poverty × emigrant stock & 0.148 & 0.145 & & \\
& $(2.84)$ & $(2.72)$ & & \\
\hline Immigration policy: total US & & 0.327 & 0.321 & 0.299 \\
quota/population of all source countries & & $(2.64)$ & $(3.33)$ & $(2.86)$ \\
\hline Period dummies & Yes & No & No & No \\
\hline $\mathrm{R}^{2}$ (within) & 0.439 & 0.398 & 0.386 & 0.271 \\
\hline $\mathrm{R}^{2}$ (between) & 0.925 & 0.896 & 0.915 & 0.001 \\
\hline Countries & 62 & 62 & 62 & 62 \\
\hline Observations & 434 & 434 & 434 & 434 \\
\hline
\end{tabular}

Notes: fixed effects estimation on a balanced panel of five year total immigration for fiscal years-e.g. 1970-4 is fiscal years 1970/1 to 1974/5. All other variables are for the beginning of each five year period, e,g, 1970 or 1985.

Sources: See Appendix. 
Table 5

Actual and Predicted Log Migration, 1970-4 to 2000-4 (log points deviation from mean)

\begin{tabular}{|l|r|r|r|r|r|r|}
\hline & \multicolumn{2}{|c|}{$\begin{array}{c}\text { Latin America and } \\
\text { Caribbean (24) }\end{array}$} & \multicolumn{2}{c|}{$\begin{array}{c}\text { Asia, Middle East and } \\
\text { North Africa (25) }\end{array}$} & \multicolumn{2}{c|}{$\begin{array}{c}\text { Sub-Saharan Africa } \\
(13)\end{array}$} \\
\hline & Actual & Predicted & Actual & Predicted & Actual & Predicted \\
\hline $1970-4$ & -0.36 & -0.44 & -0.39 & -0.42 & -0.91 & -0.56 \\
\hline $1975-9$ & -0.08 & -0.25 & -0.16 & -0.19 & -0.35 & -0.33 \\
\hline $1980-4$ & -0.13 & -0.18 & -0.01 & -0.14 & -0.19 & -0.24 \\
\hline $1985-9$ & 0.31 & 0.22 & 0.13 & 0.25 & 0.13 & 0.15 \\
\hline $1990-4$ & 0.25 & 0.20 & 0.26 & 0.17 & 0.32 & 0.19 \\
\hline $1995-9$ & -0.03 & 0.23 & 0.01 & 0.17 & 0.45 & 0.33 \\
\hline $2000-4$ & 0.04 & 0.22 & 0.16 & 0.17 & 0.55 & 0.45 \\
\hline
\end{tabular}

Table 6

Contributions to Trends in Log Migration 1970-4 to 2000-4 (difference in log points)

\begin{tabular}{|l|r|r|r|r|r|}
\hline & \multicolumn{2}{|c|}{$\begin{array}{c}\text { Latin America and } \\
\text { Caribbean (24) }\end{array}$} & \multicolumn{2}{c|}{$\begin{array}{c}\text { Asia, Middle East and } \\
\text { North Africa (25) }\end{array}$} & $\begin{array}{l}\text { Sub-Saharan } \\
\text { Africa (13) }\end{array}$ \\
\hline & $\begin{array}{l}1970-4 \text { to } \\
1990-4\end{array}$ & $\begin{array}{l}1990-4 \text { to } \\
2000-4\end{array}$ & $\begin{array}{l}1970-4 \text { to } \\
1990-4\end{array}$ & $\begin{array}{l}1990-4 \\
2000-4\end{array}$ & $\begin{array}{l}1970-4 \text { to } \\
2000-4\end{array}$ \\
\hline Birth Cohort & 0.07 & -0.08 & 0.02 & -0.03 & 0.08 \\
\hline Migrant Stock & 0.38 & 0.12 & 0.87 & 0.35 & 0.65 \\
\hline Income Gap & 0.08 & 0.03 & -0.06 & 0.03 & 0.28 \\
\hline Education Gap & 0.05 & 0.02 & -0.33 & -0.13 & 0.11 \\
\hline Poverty & 0.00 & 0.00 & -0.01 & 0.01 & -0.14 \\
\hline Poverty×Stock & 0.01 & 0.01 & 0.01 & 0.03 & 0.08 \\
\hline Sum & 0.60 & 0.10 & 0.50 & 0.27 & 1.05 \\
\hline Actual & 0.67 & -0.27 & 0.52 & 0.03 & 1.46 \\
\hline
\end{tabular}


Table 7

Time Trends in Fundamentals, 1970-4 to 2000-4

\begin{tabular}{|c|c|c|c|c|}
\hline & Birth cohort & Log GDP ratio & $\begin{array}{l}\text { Log education } \\
\text { years ratio }\end{array}$ & Poverty \\
\hline & \multicolumn{4}{|c|}{ Latin America and Caribbean (24 countries) } \\
\hline Time & $\begin{array}{r}0.0164 \\
(7.81)\end{array}$ & $\begin{array}{r}0.0603 \\
(10.34)\end{array}$ & $\begin{array}{r}-0.0480 \\
(11.97)\end{array}$ & $\begin{array}{r}-0.0017 \\
(5.86)\end{array}$ \\
\hline \multirow[t]{2}{*}{ Time squared } & $\begin{array}{r}-0.0021 \\
(12.65) \\
\end{array}$ & & & $\begin{array}{r}0.0001 \\
(4.10) \\
\end{array}$ \\
\hline & \multicolumn{4}{|c|}{ Asia, Middle East and North Africa (25 countries) } \\
\hline Time & $\begin{array}{r}0.0177 \\
(5.97) \\
\end{array}$ & $\begin{array}{r}-0.0212 \\
(2.02) \\
\end{array}$ & $\begin{array}{r}-0.099 \\
(13.79) \\
\end{array}$ & $\begin{array}{r}-0.0134 \\
(2.27) \\
\end{array}$ \\
\hline Time squared & $\begin{array}{r}-0.0022 \\
(9.03) \\
\end{array}$ & & & $\begin{array}{r}0.0015 \\
(2.09) \\
\end{array}$ \\
\hline & \multicolumn{4}{|c|}{ Sub-Saharan Africa (13 countries) } \\
\hline Time & $\begin{array}{r}0.0144 \\
(8.18)\end{array}$ & $\begin{array}{r}0.1611 \\
(9.90)\end{array}$ & $\begin{array}{r}-0.0763 \\
(8.36)\end{array}$ & $\begin{array}{r}0.0329 \\
(1.78)\end{array}$ \\
\hline Time squared & $\begin{array}{r}-0.0011 \\
(7.45)\end{array}$ & & & \\
\hline
\end{tabular}

Table 8

Predicted Trends in Log Migration Rate from 2000-4 to 2020-4 (difference in log points)

\begin{tabular}{|l|r|r|r|}
\hline & $\begin{array}{c}\text { Latin America and } \\
\text { Caribbean (24) }\end{array}$ & $\begin{array}{c}\text { Asia, Middle East \& } \\
\text { North Africa (25) }\end{array}$ & $\begin{array}{c}\text { Sub-Saharan Africa } \\
\text { (13) }\end{array}$ \\
\hline Birth Cohort & -0.21 & -0.22 & -0.06 \\
\hline Income Gap & 0.07 & -0.03 & 0.21 \\
\hline Education Gap & 0.05 & 0.11 & 0.09 \\
\hline Poverty & 0.00 & 0.08 & -0.26 \\
\hline Stock Dynamics & 0.00 & 0.08 & 0.21 \\
\hline Sum & -0.09 & 0.01 & 0.19 \\
\hline
\end{tabular}


Figure 1

Stylized Emigration Responses

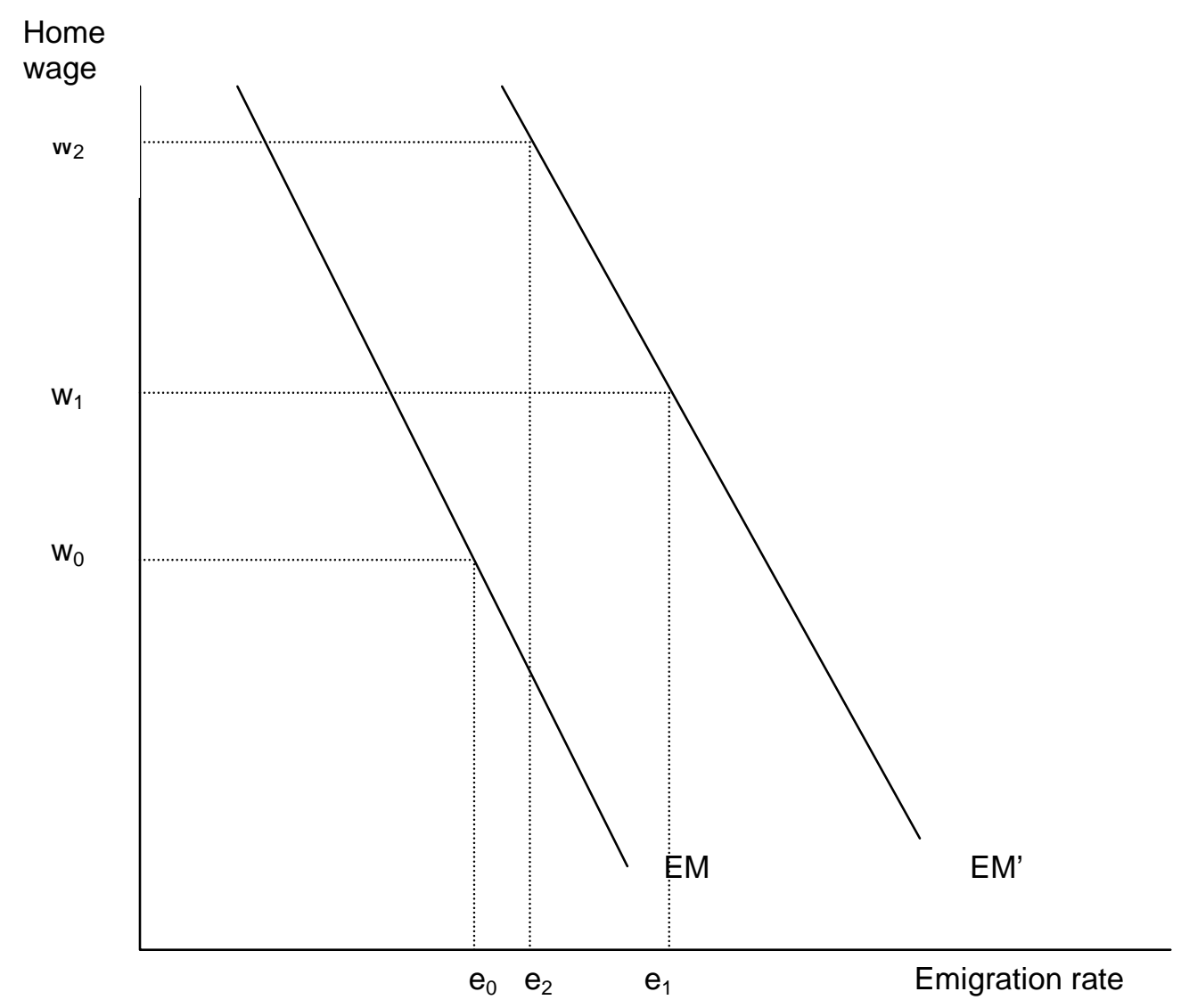


Figure 2

The Evolution of Supply to Demand Constrained Emigration

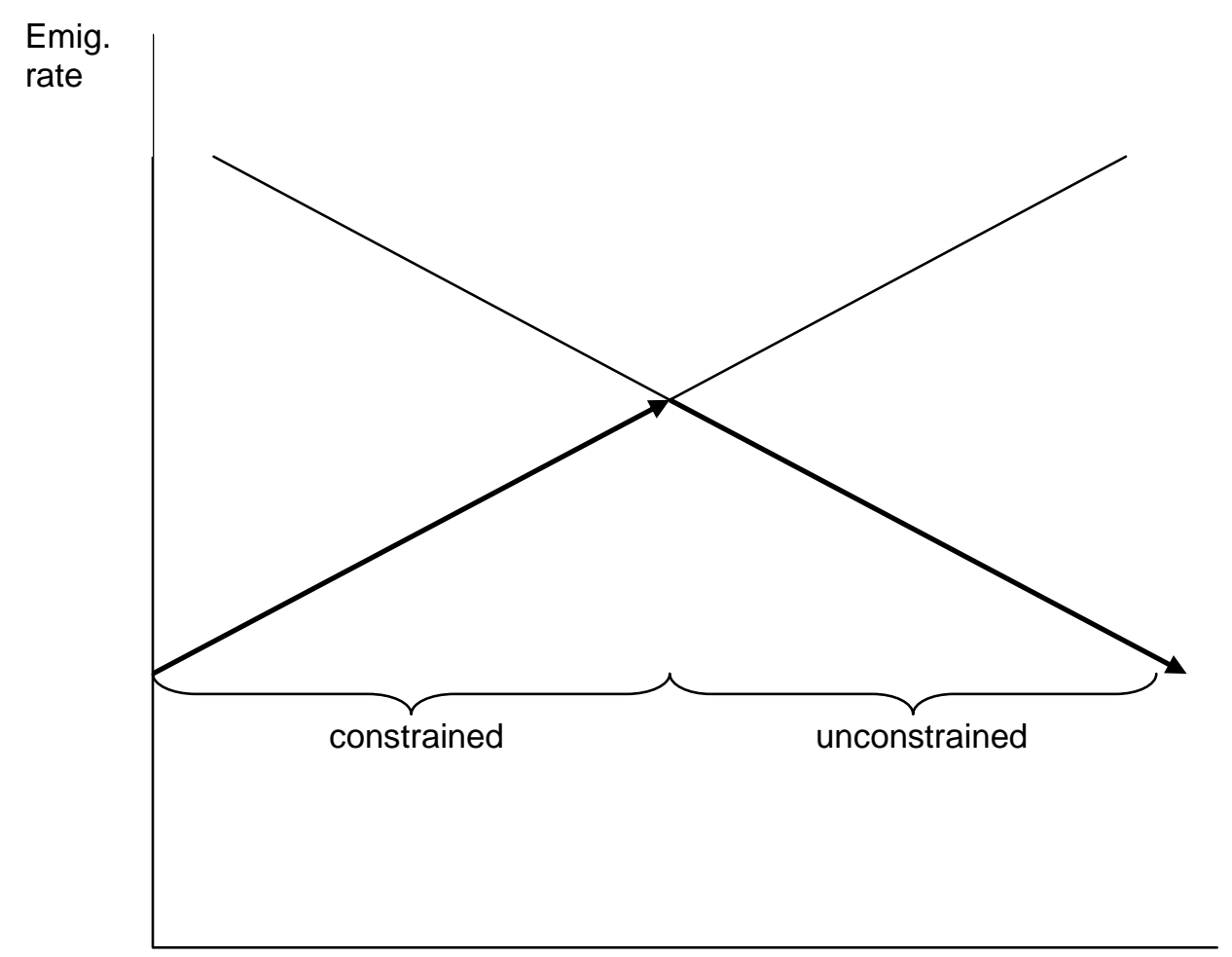

Home wage 